DOI: 10.15393/j9.art.2020.8702

УДК 821.411.21

А. А. Садыхова

Университет им. А. Мицкевича в Познани

(Познань, Польша)

sadykhova.arzu@yandex.ru

\title{
История о Кайсе и Яюбне в средневековом арабском фольклоре
}

Аннотация. Средневековая арабская литература богата преданиями о влюбленных поэтах-бедуинах, которые жили в доисламские и исламские времена. К концу IX в. эти сказания оформились в самостоятельный жанр, подчинявшийся определенным эстетическим принципам и нормам. Одно из таких преданий - история о Кайсе ибн Зарихе и его возлюбленной Любне - имеет ряд особенностей, в том числе два варианта окончания трагический и счастливый. В статье предпринята попытка проследить процесс формирования этой истории, чтобы выяснить причины появления двух версий окончания и рассмотреть ее другие уникальные черты. История о Кайсе и Любне имеет доисламский прототип - рассказ об 'Абдаллахе ибн аль-Аджлане и Хинд. Следы этого рассказа сохранились в истории о Кайсе и Любне: в ней содержатся элементы старого канона повести о несчастных влюбленных (женитьба героев, а затем их развод по принуждению родителей, разлука, отчаяние и смерть) и новой модели - узритского сказания, появившегося после распространения ислама как реакция на новые эстетические ценности, культивировавшие целомудренную любовь. С появлением политических разногласий в исламе и усилением роли шиитов в историю о Кайсе и Любне (вероятнее всего, в VIII в.) был добавлен ряд новых деталей и счастливый конец, в которых нашли отражение философские противоречия между суннитским и шиитским исламом. Именно эти моменты обусловили уникальность истории о Кайсе ибн Зарихе и Любне среди остальных узритских сказаний.

Ключевые слова: Кайс ибн Зарих, Любна, устная традиция, узритская любовная история, доисламское любовное сказание, доисламская арабская литература, раннесредневековая мусульманская литература

Об авторе: Садыхова Арзу Ахмедовна - доктор филологических наук, профессор, руководитель секции арабистики и исламоведения, Факультет неофилологии, Университет им. А. Мицкевича в Познани (al. Niepodległości 24, <61-714>, Познань, Польша)

Дата поступления: 08.02.2020

Дата публикации: 30.10 .2020

Для цитирования: Садыхова А. А. История о Кайсе и Любне в средневековом арабском фольклоре // Проблемы исторической поэтики. 2020. — T. 18. — № 4. — C. 38-66. DOI: 10.15393/j9.art.2020.8702

(C) А. А. Садыхова, 2020 


\section{1. Введение в проблематику}

И стории о влюбленных парах очень популярный и достаточно развитый жанр во многих литературах мира, и в этом смысле арабская литература не является исключением. В доисламские времена среди арабских племен, которые вообще отличались искренней любовью к слову и красноречию, было очень развито искусство повествования, о чем свидетельствует известный памятник доисламского арабского фольклора «Дни арабов», записанный уже после возникновения ислама видным филологом Абу 'Убейдой (728-825)1. Этот памятник представляет собой собрание отдельных рассказов о межплеменных войнах и распрях, однако иногда в канву таких исторических преданий помещались небольшие любовные рассказы или эпизоды, которые являлись частью биографий известных племенных поэтов, особенно если эти поэты были еще и смелыми воинами. Примером может послужить история любви поэта 'Антары ибн Шаддада (ум. ок. 615) из племени 'Абс к своей двоюродной сестре красавице 'Абле; эта история вошла в предание о долголетней кровопролитной войне между племенами 'Абс и Зубъян, в которой поэт-воин 'Антара принимал участие.

В первые века существования ислама стихи поэтов-бедуинов бытовали в устной форме, как и почти все словесное искусство арабов того времени. Но если творчество большинства поэтов отличалось определенным разнообразием форм и жанров, то поэтическое наследие некоторых поэтов-бедуинов составляла исключительно любовная лирика в форме отдельных небольших стихотворений, в которых воспевалась одна-единственная возлюбленная, и ее имя упоминалось едва ли не в каждом фрагменте. Поэтому со временем из комментариев к таким лирическим стихам появились полулегендарные романтические истории о влюбленных поэтах, заменившие им биографии. Очевидно, что такие истории генетически были связаны с насибом - любовной частью доисламской $\kappa a c b l d b$, которая представляла собой большую лирическую поэму, подчинявшуюся определенным композиционным и эстетическим принципам. «В насибе поэт рассказывает 
о былых любовных переживаниях, о страсти и ревности, описывает возлюбленную и свидания с ней. Развитие этой жанровой формы связано с культом возлюбленной, который напоминает, а в известном смысле и предвосхищает средневековый европейский культ дамы. В самостоятельном виде любовные стихотворения в древнеарабской поэзии встречаются крайне редко», - отмечает И. М. Фильштинский [Фильштинский: 58]. Так как поэтическое наследие этих авторовбедуинов имеет общие жанровые характеристики, исследователи условно называют их творчество «узритской лирикой» (см. [Dayf: 359], [Фильштинский: 220], [Jayyusi: 421], [Jacobi, 1998b: 789-791] и др.) по имени йеменского племени Бану 'Узра, к которому принадлежали самые первые известные поэтыбедуины 'Урва ибн Хизам (ум. ок. 650) и Джамиль ибн Маммар (ум. 701), воспевавшие неразделенную «платоническую» любовь к одной-единственной женщине ${ }^{2}$. А поскольку все истории об этих несчастных влюбленных также имеют общие черты и принципы построения, что будет показано ниже, к ним можно применить термин the 'Udrī love story [Kilpatrick, 1994: 358].

Необходимо сделать несколько важных пояснений для читателей, не знакомых с жанровой системой средневековой арабской литературы. Дело в том, что система поэтических жанров и соответствующих им терминов была достаточно развита у арабов с давних пор (см.: [Фильштинский: 50-64]), что объясняется особой ролью поэтов и поэзии в раннесредневековом обществе [Грязневич]. Напротив, прозаические жанры в течение длительного времени находились в зачаточном состоянии [Халидов], поэтому и термины для их обозначения были разработаны гораздо позжез. В рассматриваемый период времени (VII-X вв.) авторы-составители литературных антологий для обозначения прозаического отрывка-эпизода употребляли термин хабар, что значит «сообение», «известие», либо реже зикр - «упоминание», «воспоминание», «рассказ». Более точно хабар можно определить как небольшой устный прозаический рассказ, в основе которого лежат реальные события [Оганесян: 69]. Хабар являлся самой мелкой композиционной единицей средневековых арабских письменных памятников; 
каждый хабар имел свой иснад, то есть цепь передатчиковинформаторов, от которых автор-составитель услышал данное предание. Множественное число термина хабар - ахбар как совокупность хабаров - использовалось для обозначения ряда взаимосвязанных эпизодов о каком-то важном событии или известном человеке. Принимая во внимание то обстоятельство, что селекция хабаров для каждой истории целиком зависела от вкуса составителя антологии, их количество и качество в каждой истории о том или ином поэте было индивидуально и могло сильно отличаться даже в пределах одного сочинения, как будет показано ниже. Поэтому в данной работе в качестве эквивалентов для истории под названием Ахбар Кайс ва-Любна, что дословно значит «Сведения о Кайсе и Любне», будут использоваться термины «история», «предание», «сказание».

Арабская письменная традиция не зафиксировала исполнительские аспекты подобных произведений, и современный исследователь имеет в своем распоряжении только критические издания текстов этих фольклорных произведений, отредактированных позже арабскими филологами. Мы можем лишь предполагать, как могли исполняться сказания о влюбленных поэтах-бедуинах. Скорее всего, прозаическую часть просто рассказывали, а стихи пели под аккомпанемент, как это описано в одной из антологий, о чем будет сказано ниже. А возможно, стихи пели даже без инструментального сопровождения - словом, все зависело от таланта и фантазии сказителяимпровизатора. Можно также предположить, что в разных частях обширного арабского халифата существовали различные варианты исполнения.

\section{2. Узритское сказание: жанровые характеристики и исследования}

С распространением ислама и утверждением письменной традиции эти истории к концу IX в. оформились в самостоятельный жанр, обладающий определенными характеристиками (см.: [Садыхова: 120]). Каноничность в таких историях проявляется в одинаковой композиции и идентичном наборе сюжетных компонентов. Это сказания о несчастных влюбленных, 
насильно разлученных родителями и обстоятельствами: возлюбленную выдавали замуж за другого; влюбленные вынуждены были страдать в разлуке, встречаясь иногда тайком, обмениваясь письмами или предметами; поэт болел, чах от тоски, терпел лишения, сходил с ума и в конце концов умирал; узнав о смерти поэта, его возлюбленная тоже умирала или же умирала одновременно с ним, почувствовав его смерть. Таковы рассказы о поэтах-бедуинах VII-VIII вв.: 'Урве ибн Хизаме и 'Афре, Джамиле ибн Ма'маре и Бусейне, Таубе ибн Хумаййире и Лейле аль-Ахъялиййе, Кайсе ибн Зарихе и Любне, Кусаййире и 'Аззе др. Самой известной влюбленной парой в этой плеяде является пара Кайс ибн аль-Муляввах по прозвищу Маджнун ${ }^{4}$ (ум. 688) и его возлюбленная Лейла. Эта сентиментальная история о безумном поэте, потерявшем рассудок от неразделенной любви, органично вошла также в литературы иранских и тюркских народов, а мотив безумия от любви к единственной возлюбленной, получив мистическую окраску, широко распространился в суфийской литературе.

Композиционно каждая такая история представляет собой цепочку отдельных, иногда не связанных между собой логически элементов, которые в свою очередь состоят из прозаических эпизодов-хабаров с иснадами и стихов, привязанных к ним. Следует отметить, что в этих историях заметно довольно четкое разграничение функций поэтических и проза-

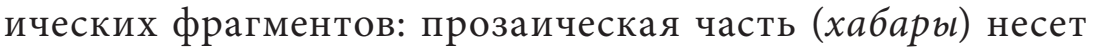
в основном повествовательную нагрузку, объясняя обстоятельства и причины появления каждого поэтического фрагмента, тогда как поэтическая часть выполняет главным образом функцию эмоционально-эстетическую. Схематично узритские сказания можно представить следующим образом: происхождение героев $\rightarrow$ их знакомство $\rightarrow$ сватовство поэта и отказ родителей возлюбленной $\rightarrow$ брак возлюбленной с мужчиной из другого племени $\rightarrow$ болезнь, одержимость и безумие поэта $\rightarrow$ встречи влюбленных, вопреки запретам $\rightarrow$ жалоба отца девушки халифу и разрешение безнаказанно убить поэта $\rightarrow$ страдания влюбленных вдали друг от друга $\rightarrow$ скитания поэта $\rightarrow$ гибель влюбленных [Садыхова: 120-126]. 
Отдельные сказания о несчастных влюбленных периодически попадали в поле зрения исследователей [Husayn], [Крачковский], [Фотиева]; биографий и творчества поэтов вскользь касались авторы общих работ по истории арабской литературы (см. [Brockelmann, 201655], [Grunebaum], [Bielawski], [Фильштинский], [Dayf] и др.), а также исследователи любовной лирики Омейядского периода, отмечая их сходство и полулегендарный характер [Kinany], [Khairallah], [Jayyusi], [Jacobi, 1998b]. Сравнительному анализу повествовательных фрагментов некоторых историй и их особенностям посвящены три работы автора этих строк [Садыхова], [Sadykhova, 2018a, 2018b]. Одна статья касается общих вопросов композиции the romance of Qays and Lubnā в рамках единой концепции «Книги песен» аль-Исфахани [Kilpatrick, 1994], другая работа посвящена опровержению мифа о платонической любви story of Qays ibn Dharīh and Lubnā love, а также story of Mağnūn and Laylā [Skarzynska-Bochenska]. Однако история о Кайсе ибн Зарихе и его возлюбленной Любне никогда прежде не была предметом детального исследования в контексте формирования канона истории о влюбленном поэте-бедуине в средневековом арабском фольклоре.

Казалось бы, жесткие рамки средневекового литературного канона исключают проявление индивидуальности и свободы варьирования, однако это не так, ведь средневековый слушатель, руководствуясь эстетикой «привычного», ждал от сказителя не нового сюжета, а искусных вариаций на известный всем сюжет ${ }^{6}$. Поэтому уже к концу Х в. известный арабский библиограф Ибн ан-Надим (ум. 998) в своем энциклопедическом справочнике «аль-Фихрист» («Каталог») перечисляет более двух десятков таких историй о влюбленных поэтах [Ibn an-Nadīm: 425-426]. Среди них сказание о Кайсе ибн Зарихе (ум. ок. 680) представляет особый интерес, потому что в нем такая индивидуальность проявляется очень ярко. Недаром выдающийся египетский исследователь Таха Хусейн (1889-1973) в свое время обратил внимание на художественные особенности этой истории, высоко оценив ее [Husayn: 204], а И. М. Фильштинский подчеркнул: «На фоне сравнительно однотипных “биографий” большей части узритских лириков несколько своеобразной представляется 
судьба поэта Кайса ибн Зариха (ум. ок. 687 г.) и его “дамы сердца” Лубны» [Фильштинский: 232]. Вне всякого сомнения, эта история заслуживает пристального внимания, потому что может пролить свет на детали процесса сложения канона предания о влюбленном поэте-бедуине в средневековом арабском фольклоре.

\section{3. История о Кайсе и Любне в ранних литературных антологиях: развитие сюжета}

Данная история примечательна двумя фактами, выделяющими ее среди остальных узритских сказаний: во-первых, тем, что герои вначале были женаты, но развелись под давлением родителей и каждый из них вступил в повторный брак с другим персонажем; во-вторых, тем, что эта история единственная из всех ей подобных имеет два конца - печальный и счастливый. Эти факты свидетельствуют о том, что в истории о Кайсе ибн Зарихе канонические принципы узритского сказания по каким-то причинам не были реализованы в полной мере. Действительно, почему герои развелись, если их чувства были настолько сильны? Как и почему именно в этом узритском сказании мог появиться happy end вопреки существовавшим в то время эстетическим нормам? Ответы на поставленные вопросы могут дать лишь оригинальные источники, а для этого необходимо обратиться к самым ранним литературным антологиям, чтобы сравнить с другими подобными историями и проследить, как изменялся жанр во времени.

Основными источниками для данного исследования послужили две известные литературные антологии — «Книга о поэзии и поэтах» ученого-филолога Ибн Кутайбы ад-Динавари (ум. 889), который впервые зафиксировал отдельные истории о влюбленных поэтах-бедуинах, и знаменитая «Книга песен» выдающегося филолога и музыканта Абу-ль-Фараджа альИсфахани (ум. 967), который собрал и тщательно записал все версии таких произведений, известных к середине X в. ${ }^{7}$

\section{1. История о Кайсе и Любне в «Книге о поэзии и поэтах» Ибн Кутайбы}

Вариант истории, представленный в «Книге о поэзии и поэтах», очень короткий даже по сравнению с другими 
подобными сказаниями ${ }^{8}$, и стихов в нем содержится совсем немного, всего 14 строк, разбитых на четыре небольших фрагмента по три и четыре бейта. Прозаическая часть истории настолько мала, что уместно привести ее здесь целиком.

«Кайс ибн Зарих происходил из [племени] Бану Кинана Бани Лайс; он [один] из арабских влюбленных [поэтов], прославившихся этим (своей любовью. - A. С.). Его возлюбленную звали Любна, и он посвящал ей стихи. Любна была женой Кайса, но он развелся с ней, и после этого душа Кайса устремилась за Любной, а его страсть к ней сделалась невыносимой. Кайс стал приходить к ее жилищу тайком от своих родственников, и тогда отец Любны выдал ее замуж за человека из племени Гатафан, но Кайс все равно продолжал с ней видеться. Узнав об этом, отец девушки обратился к Муавие ${ }^{10}$ с жалобой, в которой сообщил, что Кайс преследует его дочь, и тогда халиф разрешил отцу Любны безнаказанно пролить кровь поэта ${ }^{11}$, если Кайс еще раз придет к ней» [Ibn Qutayba: 399-400].

На этом рассказ Ибн Кутайбы обрывается, и конца у него еще нет. Анализ других историй о влюбленных поэтах-бедуинах в антологии Ибн Кутайбы (о Маджнуне и Лейле, о Джамиле и Бусейне, об Урве и Афре, о Кусаййире и 'Аззе) показал, что к концу IX в. сюжетно-композиционный канон узритского сказания уже приобрел более или менее ясные очертания, потому что все остальные рассказы о влюбленных поэтахбедуинах имеют почти полный набор повествовательных компонентов, упомянутых выше. Однако в этой истории отсутствует не только конец, но и некоторые другие обязательные компоненты повествования: знакомство героев, а также сватовство поэта. Отсутствие конца удивительно еще и потому, что антология Ибн Кутайбы предназначалась для широкого круга читателей, которым вряд ли бы понравился незавершенный рассказ. В то же время наличие в истории стержневого элемента - одержимости, а также других обязательных компонентов (брак Любны с другим мужчиной, встречи влюбленных, жалоба халифу) позволяет отнести ее к группе узритских сказаний. Ясно одно: данная история по каким-то причинам начала развиваться в направлении канона узритского сказания позже других преданий. Во всяком 
случае, здесь мы сталкиваемся с еще одной загадкой, ответ на которую, возможно, подскажет следующий по времени источник - «Книга песен».

\section{2. История о Кайсе и Любне в «Книге песен» Абу-ль-Фараджа аль-Исфахани}

Аль-Исфахани начинает свое повествование с очень подробной генеалогии поэта, чье историческое существование не подлежит сомнению [Seidensticker: 635]. Поэт происходил из многочисленного племени Бану Лайс Бани Бакр ибн Абд Манат ибн Кинана, которое обитало в окрестностях Медины. Это племя находилось в близком родстве с племенем Курайш, из которого происходил пророк Мухаммад (ум. 632); может быть, поэтому несколько информаторов Абу-ль-Фараджа альИсфахани сообщают, что мать Кайса была кормилицей Ху-

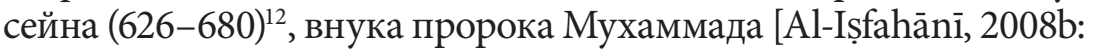
133]. Весьма вероятно также, что данная информация была необходима для того, чтобы подчеркнуть историчность поэта и его близость к семье самого пророка. Вот краткое содержание этой истории по «Книге песен».

Однажды Кайс отправился по делам в лагерь племени Бану Ка'б бен Хуза'а. Проходя мимо одной из палаток, он попросил напиться, и воду ему вынесла высокая стройная девушка по имени Любна, покорившая поэта своей красотой и манерами. Кайс влюбился в нее с первого взгляда. Поэт вернулся домой, но образ Любны продолжал преследовать его, и Кайс стал посвящать ей стихи, которые быстро распространились среди людей, так что о чувстве Кайса к Любне стало всем известно. Встретившись с девушкой снова, поэт признался ей в любви, и оказалось, что Любна тоже его любит. Счастливый влюбленный немедленно попросил у своего отца разрешения жениться на своей избраннице, однако получил отказ, потому что Зарих был богатым человеком и опасался, что его имущество может перейти в другое племя, ведь Кайс был его единственным сыном ${ }^{13}$. Тогда на помощь поэту пришел его молочный брат Хусейн ибн 'Али ибн Аби Талиб, который сумел уговорить отца Кайса сосватать Любну для сына. Герои поженились, но вскоре оказалось, что Любна бездетна, поэтому родители Кайса стали настаивать на разводе. Поэт долго сопротивлялся, однако упрямый Зарих 
все-таки добился своего. Он поклялся сыну, что будет стоять неподвижно под палящим солнцем до тех пор, пока Кайс не разведется со своей женой. Видя, как страдает отец на протяжении сорока дней ${ }^{14}$, Кайс был вынужден покориться.

«Рассказывали, что как только Кайс произнес слова развода, рассудок покинул его, и пристало к нему что-то вроде безумия. Он рыдал, вспоминая Любну, прожитые с ней дни, и горько сожалел о том, что сделал» [Al-Ișfahānī, 2008b: 136]. За Любной приехал отец, чтобы забрать ее домой, и Кайс, понимая, что теперь ему не позволят поехать с ней, долго смотрел вслед каравану, увозившему его возлюбленную, а затем упал на колени и, плача, стал целовать следы верблюда, на котором уехала Любна.

От тоски по возлюбленной поэт заболел и слег; ни врачи, ни лекарства ему не помогали. Чтобы прекратить страдания сына, отец предложил ему жениться на другой, но Кайс наотрез отказался; тогда отец посоветовал ему отправиться в путешествие. И вот, как-то раз, минуя лагерь племени Фазара, несчастный поэт встретил высокую красивую девушку, очень похожую на Любну и с таким же точно именем. Поддавшись уговорам родни, Кайс женился на ней, но сразу же после свадьбы понял, что не может ни приблизиться к своей новой жене, ни смотреть на нее, ни даже говорить с ней. В отчаянии Кайс поехал к жилищу Любны, чтобы встретиться с ней, но оказалось, что ее уже выдали замуж за бедуина из другого племени. Тем не менее поэту все же удалось увидеться с Любной под видом торговца верблюдами. Узнав об этом, рассерженный отец девушки пожаловался халифу Му'авийе на поэта, тем более что стихи о его любви к Любне распевали все в Медине и за ее пределами. За недостойное поведение халиф объявил поэта вне закона [Al-Ișfahānī, 2008b: 133-160].

Конец истории представляет особый интерес, поэтому необходимо привести его здесь в полном переводе. Вот что сообщает аль-Исфахани:

«Люди разошлись во мнениях насчет конца сказания о Кайсе и Любне; большинство рассказчиков утверждали, что они умерли от тоски в разлуке, причем одни говорили, будто сначала умер Кайс, а Любна не смогла пережить эту потерю и умерла вслед за ним; другие рассказывали, что первой умерла Любна, а Кайс вскоре умер от тоски по ней... Рассказал мне Абу 'Амр аль-Мадани: 
“Когда умерла Любна, Кайс вместе со своими родственниками пошел к ее могиле и там произнес такие стихи:

Умерла Любна... а ее смерть, это и моя смерть! Принесет ли мне моя потеря избавление? ${ }^{15}$

Я буду плакать, удрученный горем, Проведя [остаток] жизни в печали об умершей...

После этого он упал на ее могилу и рыдал, пока не лишился чувств. Родственники подняли его и принесли домой, но Кайс так и не пришел в себя. Он пролежал без сознания три дня и умер. Кайса похоронили рядом с Любной”.

Рассказывали аль-Кахзами, Ибн 'Аиша ${ }^{16}$ и Халид ибн Джамаль, что Ибн Аби 'Атик пошел к Хасану и Хусейну, сыновьям 'Али ибн Аби Талиба, 'Абдалле ибн Джаффару и группе курайшитов и обратился к ним с такими словами: “У меня есть просьба к одному человеку, но, боюсь, он мне откажет, поэтому мне нужна ваша помощь в этом деле, чтобы вы своим общественным положением повлияли на него". Те ответили: "Мы сделаем для тебя все, что в наших силах". В назначенный день они собрались, и Ибн Аби 'Атик повел их к мужу Любны. Увидев столько знатных и богатых людей в своем доме, муж Любны был очень польщен. Гости сказали: "Мы пришли сюда по просьбе Ибн Аби "Атика". “Считайте, что эта просьба выполнена, какой бы она ни была”, - заверил их хозяин дома. "И ты выполнишь мою просьбу, даже если она будет касаться твоего имущества, денег или твоей семьи?” - поинтересовался Ибн Аби “Атик. “Конечно!” тут же пообещал ему муж Любны. Тогда Ибн Аби 'Атик попросил: "Мы хотим, чтобы ты развелся со своей женой Любной”. “Свидетельствую вам трижды, что она разведена", - ответил ему супруг Любны. Поняв в чем дело, гости устыдились и попросили прощения у хозяина дома: "Клянемся Аллахом, мы не знали сути его просьбы, а если бы знали, то ни за что не попросили бы тебя об этом!” Рассказал Ибн “Аиша: “Хусейн возместил бывшему мужу Любны его потерю, выплатив тому сто тысяч дирхамов, которые доставил Ибн Аби 'Атик. После этого развода Кайс снова женился на Любне, и они прожили вместе до самой смерти. Говорят, что в знак благодарности Кайс сложил панегирик в честь Ибн Аби 'Атика. Так закончилась эта история» [Al-Iṣfahānī, 2008b: 161-162].

Как видно из приведенных выше отрывков, уже к середине $\mathrm{X}$ в. история претерпела значительные изменения. Приблизительно за 80 лет, которые разделяют эти антологии, ее состав 
существенно расширился: появились новые детали и подробности. Если в сжатой версии Ибн Кутайбы упоминался лишь халиф Му'авия, то благодаря информаторам Абу-ль-Фараджа аль-Исфахани в повествование были введены также другие реальные исторические лица, а главное, увеличилось количество стихов. Из коротенького, всего в несколько строчек, лаконичного рассказа Ибн Кутайбы история превратилась в красочное предание о бедных влюбленных, которые вначале были счастливы, но затем насильно разлучены. В подробной версии аль-Исфахани хорошо заметно развитие канона узритского сказания: сюда органично «встроены» недостающие компоненты - эпизоды знакомства героев, разлуки с мотивом безумия, страданий и встреч вопреки запретам, скитания поэта, а главное, у этой истории появились две версии окончания. При этом важно отметить, что каждая версия окончания имеет ссылки на разных передатчиков: это говорит о том, что обе версии формировались независимо друг от друга и, по-видимому, в разных социальных кругах.

Аль-Исфахани сообщает также, что история о Кайсе ибн Зарихе и его возлюбленной Любне бытовала как в виде связных рассказов со стихами, так и в форме разрозненных прозаических и стихотворных фрагментов, которые он услышал от разных информаторов и зафиксировал [Al-Ișfahānī, 2008b: 133]. Это свидетельство крайне важно, так как прямо указывает на то, что составитель «Книги песен» имел дело непосредственно с устной традицией, представив нам свою редакцию всех услышанных версий и фрагментов истории о Кайсе и Любне. По сути, к середине Х в. сказание полностью оформилось в соответствии с требованиями канона, и его дальнейшее развитие заключалось лишь в добавлении различных деталей и подробностей, например, эпизодов охоты Кайса или попытки матери развеселить страдающего сына и т. п. [AlIșfahānī, 2008b: 139, 142]. Другое важное замечание заключается в том, что это сказание, равно как и все ему подобные истории, записанные филологом и музыкантом аль-Исфахани, исполнялось под аккомпанемент, на что указывает и название книги, и сам автор в предисловии [Al-Ișfahānī, 2008a: 23] ${ }^{17}$. Здесь уместно вспомнить тезис Ю. М. Лотмана о том, что 
«слушатель фольклора скорее напоминает слушателя музыкальной пьесы, чем читателя романа» [Лотман: 318].

Сравнительный анализ структуры данной истории с другими подобными сказаниями о несчастных влюбленных из «Книги песен» выявил две любопытные особенности: во-первых, в истории о Кайсе и Любне отсутствует вариативность повествовательных компонентов и, во-вторых, эта история имеет самую сложную фабулу за счет наличия уникальных сюжетных компонентов, отсутствующих в других узритских сказаниях, а именно: брака героев, а затем их развода, повторных браков героев с другими персонажами и двух вариантов окончания. Иными словами, все эпизоды этой истории за исключением окончания не имеют вариантов и к тому же расположены в хронологической последовательности, тогда как вариативность и отсутствие всякой хронологии - характерная черта подобных историй, да и вообще многих фольклорных произведений. Например, история о Джамиле и Бусейне имеет два разных варианта знакомства героев $(1-$ росли вместе и полюбили друг друга; 2 - познакомились случайно); история о Маджнуне и Лейле содержит три версии знакомства $(1-$ росли вместе и полюбили друг друга; 2 - познакомились случайно; 3 - поэт услышал о красоте девушки и поехал с ней познакомиться); а самый варьируемый компонент таких сказаний - встреча героев - имеет несколько вариантов в каждой истории. Кроме того, в других преданиях часто нарушается последовательность повествования: варианты одного компонента располагаются не подряд, а помещаются среди вариантов другого. Лидером по степени вариативности всех сюжетно-повествовательных компонентов, включая генеалогию героя ${ }^{18}$, является сказание о Маджнуне и Лейле, что совсем не удивительно, учитывая огромную популярность этой пары в арабской литературе. Говоря о ранней версии истории о Маджнуне и Лейле, И. Ю. Крачковский отмечал: «Отсутствие единой линии развития сюжета - общее свойство всех этих повестей: все они представляют, в сущности, механическое соединение не связанных между собою рассказов...» [Крачковский: 609]. И только сказание о Кайсе и Любне является удивительным исключением из этого правила: это связная 
и завершенная история - ahbār manz̄ūma, по определению самого аль-Исфахани ${ }^{19}$, на что также обратила внимание швейцарская исследовательница [Kilpatrick, 1994: 361], однако она не затронула вопрос происхождения в истории уникальных компонентов, в том числе двух вариантов окончания. Эти данные подсказывают, что предание о Кайсе и Любне формировалось и циркулировало в достаточно узких кругах, поэтому дошло до нас без вариаций, в противном случае хотя бы некоторые его компоненты имели различные версии.

\section{4. Истоки истории о Кайсе и Любне и разгадка двух окончаний}

Теперь можно сформулировать ответы на вопросы, поставленные в начале статьи: почему Ибн Кутайба представил историю о Кайсе и Любне в таком сокращенном виде, почему герои развелись и как в «Книге песен» у истории появился happy end вопреки канону?

Текст Ибн Кутайбы явно демонстрирует негативное отношение составителя антологии к этой истории, что особенно заметно после сравнения ее с другими подобными сказаниями. Что же такого необычного в предании о Кайсе и Любне, что вызвало неприятие?

Известный писатель-энциклопедист Абу 'Усман аль-Джахиз (ум. 868) в одном из своих трактатов упоминает шесть пар несчастных влюбленных (Джамиль - Бусейна, 'Урва - 'Афра, Кусаййр - 'Азза, Кайс - Любна, Асма - Мураккиш, 'Абдаллах ибн аль-Аджлан - Хинд) как хорошо известных каждомy [Al-Ğāḥiz, a: 146] ${ }^{20}$. Значит, уже в первой половине IX в. история о Кайсе и Любне была очень популярна, поэтому Ибн Кутайба не мог не включить ее в свою антологию. Однако составителю не понравилось, что история не полностью соответствовала эстетическим требованиям канона узритского сказания: ведь герои пусть и недолго, но были женаты, а значит, счастливы какое-то время, следовательно, «платоническая», чистая любовь между ними уже была невозможна ${ }^{21}$. Кроме того, иная структура, отличная от типичного узритского сказания, могла показаться ученому мало привлекательной, поэтому Ибн Кутайба и представил ее в таком чрезвычайно 
сокращенном виде. В пользу подобного предположения свидетельствует также краткая характеристика, данная автором «Книги о поэзии и поэтах» Кайсу ибн Зариху («он [один] из арабских влюбленных [поэтов], прославившихся этим»), из чего следует, что Кайс не умер от неразделенной любви, как 'Урва ибн Хизам, о котором Ибн Кутайба высказывается более конкретно: «один из влюбленных, которых убила любовь» [Ibn Qutayba: 394]. Это означает, что хотя трагический конец в подобных историях ко второй половине IX в. уже стал нормой, сказание о Кайсе и Любне, услышанное Ибн Кутайбой, завершилось как-то иначе.

Однако тот же аль-Джахиз в другом своем трактате, подчеркивая существование множества историй о несчастных влюбленных, прямо говорит о печальном конце данного сказания:

«Среди поэтов, особенно эпохи ислама, есть несколько, которых убила любовь: так, Джамиля ибн Маммара убила любовь к Бусейне, Кусаййира убила любовь к 'Аззе, 'Урву убила любовь к 'Афре, Маджнуна [из племени] бану 'Амир свела с ума Лейла, Кайса ибн Зариха убила Любна, 'Абдаллаха ибн аль-Аджлана убила Хинд, а аль-Гамра ибн Дарара убила Джумля. И это [только] те, кого мы можем перечислить... но тех, кого мы не помним, еще больше!» [Al-Ğāḥiz, b: 104-105].

Это замечание свидетельствует о том, что трагические истории о несчастных влюбленных поэтах существовали не только в эпоху ислама, но и в доисламские времена, что позволяет предположить существование более древнего канона сказания о несчастных влюбленных, который, вероятно, предшествовал узритскому преданию. В любом случае, совершенно ясно, что уже к середине IX в. история о Кайсе и Любне циркулировала в двух вариантах - с трагическим концом и счастливым, при этом каждый из них был распространен в определенных, достаточно узких социальных кругах, на что указывают, как уже отмечалось выше, ссылки на разных передатчиков каждой версии, а также связное последовательное повествование без вариативности сюжетных компонентов. Если аль-Джахиз был знаком с печальным вариантом истории, то Ибн Кутайба, скорее всего, услышал счастливую версию предания, которая привела его в замешательство, так как не отвечала ни литературным 
вкусам, ни общим эстетическим представлениям того времени; поэтому автор решил попросту исключить из истории непривычный радостный конец. Осталось лишь выяснить, какая из двух версий появилась раньше и есть ли у данной истории более ранние предшественники.

Перечисляя хорошо известные влюбленные пары доисламского периода и начала ислама, аль-Джахиз дважды упоминает историю о доисламском поэте 'Абдаллахе ибн аль-Аджлане и его возлюбленной Хинд. Оказалось, что очень краткое предание ${ }^{22}$ об этом поэте содержится в антологии Ибн Кутайбы, и содержание его напоминает историю Кайса ибн Зариха: 'Абдаллах и Хинд были женаты, но затем развелись; вскоре после развода поэт, одержимый страстью к своей бывшей супруге, не смог пережить разлуку и умер [Ibn Qutayba: 449-450]. При этом Ибн Кутайба дает поэту такую характеристику: «Он [один] из знаменитых арабских влюбленных, погибших от любви» [Ibn Qutayba: 449]. Абу-ль-Фарадж альИсфахани представил значительно более подробную историю этой пары, охарактеризовав 'Абдаллаха как «доисламского поэта, одного из тех, кто был одержим страстью и кого убила любовь» [Al-Ișfahānī, 2008c: 166]. Автор «Книги песен» сообщает также, что причиной развода героев сказания было отсутствие у них детей и на разводе настоял отец поэта, хотя 'Абдаллах противился изо всех сил. После развода с Хинд поэт сразу же раскаялся и пожалел о том, что сделал, но девушку очень скоро выдали замуж за другого, а 'Абдаллах вскоре умер от тоски по своей возлюбленной [Al-Ișfahānī, 2008c: 166-171]. Итак, предание об 'Абдаллахе ибн аль-Аджлане и есть тот самый ранний образец любовной истории, бытовавшей среди бедуинов в доисламское время, из которого позже «выросло» узритское сказание. От любви физической, понятной и привычной для арабов в доисламские времена, произошла трансформация жанра в направлении к любви платонической, т. е. узритской, полностью соответствующей нравам нового мусульманского общества. И таких историй о несчастной любви в доисламском фольклоре, по словам аль-Джахиза, было очень много. 
Теперь ясно, что брак и развод героев «перекочевали» в историю о Кайсе и Любне из доисламского, более раннего образца жанра. Развод в сюжете был необходим для того, чтобы разлучить влюбленных и ввести необходимые элементы узритского сказания, в котором «роковая, возникшая по воле самого Аллаха, почти мистическая любовь к идеальной женщине приносит поэту (который отождествляется с обобщенным образом лирического героя узритской поэзии) одни лишь страдания, избавления от которых не сулит ему даже смерть» [Фильштинский: 220].

Исследуя общую композицию сказания о Кайсе и Любне по «Книге песен» Х. Килпатрик обратила внимание на следующее обстоятельство: «After the divorce, however, the mode of narrative is that of the conventional 'Udri love stories; the weeping, fainting-fits, illness, replying to questions by means of poems (the first section has no poems), and the repetition of standard phrases all belong to the conventions of this genre» («Но после развода способ повествования становится таким же, как в обычных узритских любовных историях; плач, обмороки, болезнь, ответы на вопросы в стихах (в первой части [истории] стихов нет), а также повторы стандартных фраз, которые являются типичными для данного жанра»)23 [Kilpatrick, 1994: 358]. Однако это не совсем так: ведь среди уникальных сюжетных компонентов обсуждаемого произведения есть еще один, происхождение и функция которого нуждаются в объяснении. Это повторный брак поэта с другой девушкой, очень похожей на его возлюбленную. Если брак героини с другим мужчиной является обязательным элементом узритского сказания, и в этом смысле брак Любны с мужчиной из другого племени является нормой, то женитьба поэта на другой девушке выглядит очень необычно в рамках канона данного жанра. Представляется, что данный элемент был введен сказителями в историю для того, чтобы рельефнее показать привязанность поэта к объекту своей страсти. Во всех узритских историях главный герой проходит сквозь испытания разлукой - обычно это странствия и скитания, которые лишь усугубляют страдания поэта. Наш герой тоже отправляется в путешествие, но его испытание «усилено» попыткой отвлечься от своей 
возлюбленной, женившись на другой, пусть и похожей на нее, девушке. Этот шаг придает герою реальные черты, свойственные обычному мужчине, который действительно пытается побороть свои чувства, чтобы перестать страдать. Однако Кайс с честью проходит это испытание: первая любовь и преданность своей возлюбленной все же оказались сильнее, и сразу после свадьбы герой ясно осознает, что никто и ничто не может заменить ему Любну. Этот компонент обостряет интригу жанра и, по сути, является поворотным моментом развития повествования, после которого и начинается «the conventional 'Ud

Ключевую роль в повествовании о Кайсе и Любне, как можно было заметить, играет уже упоминавшийся выше Хусейн, внук пророка Мухаммада, являющийся одной из центральных фигур в шиитском исламе [Veccia Vaglieri]. В других узритских историях этот персонаж не встречается. Шиитская традиция, как известно, наделила его сверхъестественными способностями совершать чудеса, поэтому вполне естественно, что в нашей истории он выступает как добрый гений, способный уладить любые проблемы героев. Это обстоятельство говорит о том, что данная история формировалась и циркулировала в шиитских кругах, и в жанре в определенном смысле нашел отражение бунтарский дух шиизма против традиционного суннитского ислама. Хусейн всячески старается изменить ход сказания и дважды помогает Кайсу: первый раз с женитьбой, уговорив отца Кайса сосватать понравившуюся сыну девушку, а во второй раз вместе со своим старшим братом Хасаном и другими знатными курайшитами уладил дело о разводе для Любны, чтобы герои смогли пожениться во второй раз и вновь обрести счастье и покой. Более того, чтобы компенсировать моральный ущерб второму мужу героини, именно Хусейн выплатил «пострадавшему» крупную сумму денег, так что все приличия и нормы исламской этики были соблюдены. Если допустить, что к середине IX в. предание уже имело «шиитскую окраску» (а скорее всего так и было), то тогда становится понятно, почему ярый суннит Ибн Кутайба так пренебрежительно отнесся к данному произведению, опустив все детали и купировав ее конец. В свою 
очередь, перс по происхождению и шиит аль-Исфахани заботливо зафиксировал все подробности этой истории, старательно привел в порядок все ее сюжетно-композиционные компоненты и представил читателю связное последовательное повествование ${ }^{24}$. Таким образом, «Книга песен» действительно подсказала нам ответ на вопрос, почему Ибн Кутайба так своеобразно представил историю о Кайсе и Любне в своей антологии.

\section{5. Особенности лирики Кайса ибн Зариха}

Поэтический материал произведения в «Книге песен» представляет особую проблему для исследователя. Дело в том, что использовать стихи Кайса ибн Зариха в качестве надежного доказательства едва ли возможно, поскольку авторство многих из них сомнительно, так же, как и авторство стихов другого Кайса - Кайса ибн аль-Мулявваха по прозвищу Маджнун. Уже в середине IX в. все тот же аль-Джахиз сетовал: «Люди приписали Маджнуну все стихи неизвестных поэтов, в которых упоминается имя Лейла, точно так же, как все стихи с именем Любна они приписали Кайсу ибн Зариху» (цит. по: [Dayf: 360-361]). Подчеркну также, что имя Лейла можно легко заменить именем Любна (и наоборот) без нарушения стихотворного размера, что позволяет одни и те же стихи приписывать обоим поэтам и, таким образом, проблема авторства еще более усложняется ${ }^{25}$.

Следует отметить также резкий дисбаланс в распределении поэтического и прозаического материала произведения по «Книге песен». В первой части повествования до момента расставания влюбленных после развода почти нет стихов, тогда как во второй его части сконцентрирована почти вся лирика. На это обстоятельство обратила внимание и Х. Килпатрик: "In the final pages before the conclusion yet another change occurs; the focus of attention moves away from Qays, who hardly appears, to his poetry. Here the prose narration serves merely to introduce the poetry...» («На последних страницах перед окончанием происходит еще одна перемена: внимание рассказчика переключается с личности Кайса, который уже почти не появляется, на его лирику, и здесь прозаическое повествование 
служит лишь для того, чтобы представить поэзию...») [Kilpatrick, 1994: 358]. Действительно, для остальных произведений характерно более или менее равномерное распределение прозы и поэзии, а также отражение в стихах основных событий: так, Джамиль вспоминает, как он познакомился с Бусейной, затем описывает их встречи, свои переживания в ожидании этих встреч, свою болезнь от любви и т. д. То же самое можно сказать о лирике Маджнуна, 'Урвы, Таубы и других поэтов-бедуинов. В стихах же Кайса почти нет упоминаний о событиях из жизни героев: о встрече с Любной, женитьбе на ней и о пережитых радостных моментах, хотя аль-Исфахани сообщает, что Кайс начал воспевать Любну в стихах сразу после первой встречи. Наоборот, поэзия Кайса ибн Зариха содержит, по меткому выражению И. М. Фильштинского, «весь арсенал тем и образов узритской лирики. Тут и рассказ о муках разлуки и о бессонных ночах, проведенных в мечтах о возлюбленной и в раздумьях о беспощадной судьбе» [Фильштинский: 233]. Добавим сюда еще традиционный мотив «ворона разлуки», и перечень лирических образов поэзии узритского типа будет абсолютно полным [Al-Ișfahānī, 2008b: 136-137]. Понятно, что такая ситуация со стихами поэта сложилась благодаря усилиям передатчиков-сказителей, которые, стараясь переделать нестандартную историю в типичное узритское сказание и придать ей надлежащие черты, щедро снабжали ее подходящими стихами с соответствующими прозаическими комментариями. К сожалению, вряд ли возможно будет установить, как обстояло дело на самом деле: может быть, ядро лирики Кайса ибн Зариха составляли его стихи о любовных переживаниях и ожиданиях встреч, когда влюбленные еще не были женаты. Возможно также, что поэт продолжал слагать стихи, находясь время от времени в разлуке со своей молодой женой, а затем и после развода. В любом случае, стихи Кайса ибн Зариха соответствуют всем характеристикам узритской лирики, которая «проникнута фатализмом, чувством безысходной тоски и обреченности» [Фильштинский: 220]. Эти стихи отражают лишь сильные эмоциональные переживания, и извлечь из них какую-либо информацию о реальной биографии поэта не представляется возможным. 


\section{6. Заключение}

Итак, проведенное исследование дает основание утверждать, что в бедуинской среде уже в доисламский период существовали истории о несчастных влюбленных, как, например, сказание об 'Абдаллахе ибн аль-Аджлане и Хинд, подчинявшиеся эстетическим принципам того времени. На значительное количество таких устных рассказов указывали аль-Джахиз и Ибн ан-Надим. С возникновением ислама, который привел к революционным изменениям во всех сферах арабского общества, эти истории были почти забыты, и только некоторые из них были зафиксированы очень кратко спустя несколько веков. Вне всякого сомнения, в основе таких рассказов лежали реальные ситуации, которые часто случались в бедуинских семьях: известно, что во многих культурах родители вмешивались в семейную жизнь своих детей, что зачастую приводило к разводам. Конечно же, нам неизвестно, каковы были в доисламское время представления бедуинов о сильной страсти, граничащей с безумием. Весьма вероятно, что такие представления были связаны с физической близостью, поэтому влюбленные герои должны были сначала пожениться, а затем расстаться против своей воли, чтобы вдали друг от друга острее и глубже осознать всю горечь потери, которую невозможно пережить.

Следы именно такого доисламского сказания сохранились в истории о Кайсе и Любне, которая является уникальным результатом устного народного творчества. По мере развития эстетических норм и принципов канона узритского сказания народная фантазия значительно обогащала деталями и подробностями исходную доисламскую трагическую версию с разводом. Таким образом, история о Кайсе и Любне содержит элементы старого примитивного канона предания о несчастных влюбленных (женитьба героев, а затем их развод по принуждению, разлука, страдания и смерть) и новой модели - узритского сказания, - появившейся в ответ на новые эстетические нормы и принципы, культивировавшие целомудренную любовь. С появлением политических разногласий в исламе и усилением роли шиитов в историю о Кайсе и Любне (вероятнее всего в VIII в.) были добавлены новые детали и счастливый 
конец, в которых нашли отражение философские противоречия между суннитским и шиитским исламом. Именно эти моменты и обусловили уникальность состава сюжетных компонентов этой истории.

Несомненно, в ходе дальнейшего развития устной традиции наличие двух вариантов окончания произведения о Кайсе и Любне оказалось выгодно рассказчикам-импровизаторам. Желая угодить аудитории, сказитель представлял слушателям тот или иной вариант в зависимости от их настроения и религиозных предпочтений, что, в общем, было свойственно импровизаторам и на что в свое время обращали внимание исследователи устной традиции [Lord: 16-17].

\section{Примечания}

1 Для удобства читателя при передаче арабских имен, литературных сочинений и терминов на русском языке использована транслитерация. В списке литературы для передачи арабских имен авторов и сочинений использована международная научная транскрипция ISO.

2 Это йеменское племя, представители которого «полюбив, умирают», стало широко известно в Европе благодаря популярному стихотворению Генриха Гейне «Азра».

3 Подробный обзор всех жанров раннесредневековой арабской литературы содержится в монографии И. М. Фильштинского [Фильштинский: 50-64, 163-170, 244-245].

4 Прозвище Маджнун в переводе с арабского значит «сумасшедший», «безумный», «одержимый».

5 Карл Брокельманн (1868-1956) отмечал, что европейские исследователи усматривали сходство сказания об 'Урве ибн Хизаме с французским романом «Флуар и Бланшфлер», а в истории о Кайсе ибн Зарихе находили элементы второй части романа о Тристане и Изольде [Brockelmann, 2017: 81].

6 О проблеме свободы творчества и принципе «привычного» в средневековой арабской поэзии см. монографию Б. Я. Шидфар [Шидфар: 11-12]. Подобный подход применим также к прозаическим произведениям арабского фольклора.

7 Читатель может познакомиться с биографиями этих ученых и их трудами в исследовании, посвященном Ибн Кутайбе [Оганесян], и в предисловии А. Б. Халидова к избранным переводам из «Книги песен» [аль-Исфахани: 5-16].

8 Для сравнения: самая длинная история о Маджнуне и Лейле занимает 10 страниц печатного текста; о Джамиле и Бусейне - 9; об 'Урве и 'Афре - 4,5 страницы, тогда как история о Кайсе и Любне вместе со стихами - всего 1 страницу. 
9 Здесь и далее переводы А. А. Садыховой.

10 Му'авия ибн Аби Суфьян (603-680) - основатель династии Омейядов, первый омейядский халиф; правил с 661 по 680 гг.

11 Выражение «безнаказанно пролить чью-то кровь» в средние века означало «объявить кого-то вне закона», «убить безнаказанно» за нарушение социально-этических норм.

12 Хусейн (ум. 680) был внуком пророка Мухаммада, сыном двоюродного брата и зятя пророка 'Али ибн Аби Талиба (ум. 661), четвертого праведного халифа. Хусейн считается третьим имамом в шиитском исламе имамитского толка [Veccia Vaglieri].

13 Этот эпизод также демонстрирует отклонение от канона узритского сказания, согласно которому родители девушки отказываются выдать ее замуж за поэта. Здесь же мы видим обратную ситуацию: отец поэта не соглашается на женитьбу сына.

14 По версии другого информатора, отец Кайса простоял так целый год [Al-Ișfahānī, 2008b: 135].

15 То есть даже смерть не избавит поэта от страданий в загробной жизни.

16 Известный певец и композитор, жил в начале VIII в. в Медине [Kilpatrick, 1998: 308].

17 О связи средневековой арабской поэзии и музыки см. достаточно информативные статьи [Jacobi, 1998a], [Wright].

18 Аль-Исфахани зафиксировал несколько версий происхождения поэта по прозвищу Маджнун [Крачковский: 600-601], что является доказательством того, что это все же собирательный образ; этим же фактом, по-видимому, объясняется и высокая степень вариативности сюжетных компонентов данной истории.

19 A $\underline{h} b \bar{a} r$ manżuma (ахбар манзума) означает «упорядоченные сообщения», «последовательное повествование».

20 Автор перечисляет пары именно в таком порядке, из чего можно сделать более или менее точный вывод о степени популярности каждой пары: Кайс и Любна занимают здесь среднюю позицию.

21 Что и доказала польская исследовательница [Skarzynska-Bochenska].

22 Сказание об 'Абдаллахе ибн аль-Аджлане содержит всего 6,5 строк прозаического текста и только 3 бейта стихов.

23 Представляя читателю эту историю, аль-Исфахани даже ввел уже упоминавшийся специальный термин - ахбар манзума («упорядоченные сообщения»), который больше нигде не встречается. Это указывает на особое отношение составителя к произведению. Исследованию этого термина посвящена статья [Kilpatrick, 1994].

24 На это обращал внимание еще И. Ю. Крачковский, отмечая, что «количество стихов Ибн Зариха, приписываемых Маджнуну, особенно велико» [Крачковский: 628-629]. 


\section{Список литературы}

1. Аль-Исфахани, Абу-ль-Фарадж. Книга песен / пер. с арабского А. Б. Халидова и Б. Я. Шидфар. Введение А. Б. Халидова. — М.: Наука, Главная редакция восточной литературы, 1980. - $671 \mathrm{c}$.

2. Грязневич П. А. Развитие исторического сознания арабов (VI-VIII вв.) // Очерки истории арабской культуры V-XV вв. - М.: Наука, Главная редакция восточной литературы, 1982. - С. 75-155.

3. Крачковский И. Ю. Ранняя история повести о Маджнуне и Лейле в арабской литературе // Крачковский И. Ю. Избр. соч.: в 6 т. - М.; Л.: Изд-во АН СССР, 1956. - Т. 2. - С. 588-632.

4. Лотман Ю. М. Каноническое искусство как информационный парадокс // Лотман Ю. М. Статьи по семиотике культуры и искусства. - СПб.: Гуманитарное агентство «Академический проект», 2002. - С. 314-321.

5. Оганесян Д. А. «Книга поэзии и поэтов» Ибн Кутайбы (828-889). Ереван: Изд-во Ереванского университета, 1986. -152 с.

6. Садыхова А. А. Формирование сюжетно-композиционного канона в средневековых арабских повестях о влюбленных поэтах-бедуинах (VII-VIII вв.) // Восток. Афро-азиатские общества: история и современность. - М.: Рос. гос. б-ка, 1994. — № 5. - С. 120-126.

7. Фильштинский И. М. История арабской литературы V - начало Х века. М.: Наука, Главная редакция восточной литературы, 1985. - 525 с.

8. Фотиева В. С. Материалы о лирических поэтах Омеядского периода (поэты-бедуины) // Вопросы истории и литературы стран зарубежного Востока. - М.: Изд-во Московского университета, 1960. - С. 24-43.

9. Халидов А. Б. Арабская литература // Краткая литературная энциклопедия: в 9 т. - М.: Сов. энцикл., 1962. - Т. 1 / гл. ред. А. А. Сурков. - 1088 стб. [Электронный ресурс]. — URL: http://feb-web.ru/feb/ kle/kle-abc/default.asp (16.03.2020).

10. Шидфар Б. Я. Образная система арабской классической литературы (VI-XII вв.). - M.: Наука, Главная редакция восточной литературы, 1974. $-256 \mathrm{c}$.

11. Al-Ğāḥiz Abū 'Uțmān. Kitāb al-qiyyān // Rasāil al-Ğāḥiz. — Al-Qāhira: Maktabat al-Hुānağīi. - No date. - Al-ğuz' 2. - 497 р. (на арабском языке). (а)

12. Al-Ğāḥiz Abū 'Uțmān. Kitāb muhāfarat al-ğawārī wa-l-gilmān // Rasāil alĞāḥiz. - Al-Qāhira: Maktabat al-Ȟānağì. - No date. - Al-ğuz’ 2. — 497 p. (на арабском языке). (b)

13. Al-Iṣfahānī Abū al-Farağ. Kitāb al-Agāāī. - Bayrūt: Dār șādir, 2008. - AlMuğallad 1. - 274 p. (на арабском языке). (a)

14. Al-Ișfahānī Abū al-Farağ. Kitāb al-Ag̉ānī. - Bayrūt: Dār șādir, 2008. - AlMuğallad 9. - 254 p. (на арабском языке). (b)

15. Al-Iṣfahānī Abū al-Farağ. Kitāb al-Ag̉ānī. - Bayrūt: Dār șādir, 2008. - AlMuğallad 22. - 238 р. (на арабском языке). (c)

16. Ḍayf Šawqī. Tārīh al-adab al-'arabì. Al-'Asr al-islāmì. - Al-Qāhira: Dār alMaārif, 1963. - Al-Muğallad 2. — 491 p. (на арабском языке). 
17. Ḥusayn Ṭāhā. Hadīị al-arbaāà. — Al-Qāhira: Dār al-Maārif. — No date. — Al-ğuz' 1. - 317 p. (на арабском языке).

18. Ibn an-Nadìm. Al-Fihrist. - No date. - 545 p. (на арабском языке).

19. Ibn Qutayba ad-Dīnawarī. Kitāb aš-šír wa-š-šu'arä. — Leiden: Brill, 1902. — 653 р. (на арабском языке).

20. Bielawski Józef. Klasyczna literatura arabska. - Warszawa: Dialog, 2012. — $351 \mathrm{p}$.

21. Brockelmann Carl. History of the Arabic Written Tradition. - LeidenBoston: Brill, 2016. - Vol. 1. - 617 p.

22. Brockelmann Carl. History of the Arabic Written Tradition. - LeidenBoston: Brill, 2017. - Supplement Vol. 1. - 1047 p.

23. Grunebaum Gustave E. von. Growth and Structure of Arabic Poetry A. D. 500-1000 // The Arab Heritage. - New York: Russell and Russell Inc., 1963. - Pp. 121-141.

24. Jacobi Renate. Singers and Musicians // Encyclopedia of Arabic Literature. London; New York: Routledge, 1998. - Vol. 2. - Pp. 724-725. (a)

25. Jacobi Renate. 'Udhrī poetry // Encyclopedia of Arabic Literature. - London; New York: Routledge, 1998. - Vol. 2. - Pp. 789-791. (b)

26. Jayyusi Salma K. Umayyad poetry // Arabic literature to the end of the Umayyad period. - London; New York: Cambridge University Press, 1983. - Pp. 387-432.

27. Khairallah A. E., Love, Madness and Poetry: An Interpretation of the Mağnūn Legend. - Beirut, 1980. - $162 \mathrm{p}$.

28. Kilpatrick Hilary. Ahbār manzūma: the romance of Qays and Lubnā in the Ag̀̄āī // Festschrift Ewald Wagner zum 65. Geburdstag. — Beirut, 1994. Band 2. Studien zur arabischen Dichtung. - Pp. 350-361.

29. Kilpatrick Hilary. Ibn 'A'isha // Encyclopedia of Arabic Literature. - London; New York: Routledge, 1998. - Vol. 2. - P. 308.

30. Kinany A. Kh. The Development of Ghazal in Arabic literature (Pre-Islamic and Early Islamic Periods). — Damascus: Syrian University Press, 1951. — 382 p.

31. Lord Albert B. The Singer of Tales. - New York: Athenium, 1971. - 309 p.

32. Sadykhova Arzu A. Formation of Plot Canon in Arabic Literature: The Case of Love Stories About Poets of Bedouins // Borders and Beyond. Orient-Occident Crossings in Literature. - Wilmington: Vernon Press, 2018. - Pp. 57-68. (a)

33. Sadykhova Arzu A. Zerwanie $\mathrm{z}$ kanonem: dwie nietypowe historie romantyczne w arabskiej literaturze średniowiecznej // Świat arabski w języku, literaturze i kulturze. - Toruń: Adam Marszałek, 2018. - S. 117-126. (b)

34. Seidensticker Tilman. Qays ibn Dharịh // Encyclopedia of Arabic Literature. London; New York: Routledge, 1998. - Vol. 2. - Pp. 635-636.

35. Skarzynska-Bochenska Krystyna. Qays et Lubnā - Mağnūn et Laylā. Le mythe de l'amour platonique selon les chercheurs arabes et européens - et mes decouvertes concernant ce sujet dans Le livre des chansons (Kitāb al-Aġānī) d' Abū al-Farağ al-Iṣbahānī (X-me siècle J. C.) // "Rocznik Orientalistyczny", 2009. - Vol. 62, 1. - Pp. 137-145. 
36. Veccia Vaglieri. (al-)Husayn b. Ali b. Abi Talib // The Encyclopaedia of Islam. - New Edition. — Leiden: Brill, 1986. - Vol. 3. - Pp. 607-615.

37. Wright Owen. Music and Poetry, Medieval // Encyclopedia of Arabic Literature. — London; New York: Routledge, 1998. — Vol. 2. — Pp. 555-556.

Arzu A. Sadykhova Adam Mickiewicz University in Poznań (Poznań, Poland) sadykhova.arzu@yandex.ru

\section{The Romance of Qays and Lubnā in Medieval Arabic Folklore}

Abstract. Medieval Arabic literature is rich in love stories about Bedouin poets who lived in pre-Islamic and Islamic times. By the end of the 9 century AD, these tales have formed an independent genre that followed certain aesthetic principles and norms. One of these stories - the romance of Qays ibn Darîh and his beloved Lubnā - is unique, for it has a number of unusual features, including two versions of an ending - tragic and happy. This article attempts to trace the process of the story formation to clarify the reason for the existence of two ending versions and discuss its other peculiarities. The study has revealed that the romance of Qays and Lubnā has a pre-Islamic prototype - the tale of 'Abdallāh Ibn al-'Ağlān and Hind. Traces of this version survived in the romance of Qays and Lubnā, which is rooted in the oral tradition: it combines the elements of the old primitive unhappy lovers canon (a marriage, then a divorce under family pressure, separation, suffering and death) and the new model - the 'Udrin love story that appeared after the rise of Islam as a reaction to new aesthetic values that cultivated chaste love. As the political disagreements emerged in Islam and the role of Ši's a Islam increased, a number of new details and a happy end were added to the story (very likely in 8 century AD), reflecting the philosophical contradictions between Sunnī and Šiı́a Islam. These points have determined the uniqueness of the story about Qays ibn Darịh and Lubnā among other 'Udrī love stories.

Keywords: Qays ibn Darịh, Lubnā, oral tradition, the 'Uḍrī love story, preIslamic love story, early Muslim literature, pre-Islamic Arabic literature

About the author: Sadykhova Arzu A. - Dr hab., professor UAM, Head of the Section of Arabic and Islamic studies, the Department of Modern Languages and Literatures, Adam Mickiewicz University in Poznań (al. Niepodległości 24, Poznań, <61-714>, Poland)

Received: February 8, 2020

Date of publication: October 30, 2020

For citation: Sadykhova A. A. The Romance of Qays and Lubnā in Medieval Arabic Folklore. In: Problemy istoricheskoy poetiki [The Problems of Historical Poetics], 2020, vol. 18, no. 4, pp. 38-66. DOI: 10.15393/j9.art.2020.8702 (In Russ.) 


\section{References}

1. Al-Ișfahānī Abū al-Farağ. Kniga pesen [The Book of Songs]. Moscow, Nauka Publ., Glavnaya redaktsiya vostochnoy literatury Publ., 1980. 671 p. (In Russ.)

2. Gryaznevich P. A. The Development of Historical Consciousness of the Arabs. In: Ocherki istorii arabskoy kultury $V-X V v v$. [Essays on the History of Arabic Culture of the 5-15 Centuries]. Moscow, Nauka Publ., Glavnaya redaktsiya vostochnoy literatury Publ., 1982, pp. 75-155. (In Russ.)

3. Krachkovskiy I. Yu. The Early History of Romance of Mağnūn and Laylā in Arabic Literature. In: Krachkovskiy I. Yu. Izbrannye sochineniya : $v$ tomakh [Krachkovsky I. Yu. Selected Works: in 6 Vols]. Moscow, Leningrad, Academy of Sciences of the USSR Publ., 1956, vol. 2, pp. 588-632. (In Russ.)

4. Lotman Yu. M. Canonical Art as an Informational Paradox. In: Lotman Yu. M. Stat'i po semiotike kultury i iskusstva [Lotman Yu. M. Articles on Semiotics of Culture and Art]. St. Petersburg, Akademicheskiy proekt Publ., 2002, pp. 314-321. (In Russ.)

5. Oganesyan D. A. «Kniga poezii i poetov»Ibn Qutayby (828-889) [“The Book of Poetry and Poets" by Ibn Qutayba]. Yerevan, Yerevan State University Publ., 1986. 152 p. (In Russ.)

6. Sadykhova A. A. Formation of Plot-Compositional Canon in Medieval Arabic Stories About Enamoured Poets of Bedouins (the 7th-8th Centuries)]. In: Vostok. Afro-aziatskie obshchestva: istoriya i sovremennost' [Orient. African-Asian Societies: History and Modern Times]. Moscow, the Russian State Library Publ., 1994, no. 5, pp. 120-126. (In Russ.)

7. Fil'shtinskiy I. M. Istoriya arabskoy literatury $V-$ nachalo $X$ veka [History of Arabic Literature of the 5th - Early 10th Centuries]. Moscow, Nauka Publ., Glavnaya redaktsiya vostochnoy literatury Publ., 1985. 525 p. (In Russ.)

8. Fotieva V. S. Data on Lyric Poets of the Umayyad Period (Poets-Bedouins). In: Voprosy istorii i literatury stran zarubezhnogo Vostoka [Issues of History and Literature of Foreign Oriental Countries]. Moscow, Moscow State University Publ., 1960, pp. 24-43. (In Russ.)

9. Khalidov A. B. Arabic Literature. In: Kratkaya literaturnaya entsiklopediya: $\checkmark 9$ tomakh [A Brief Literary Encyclopedia: in 9 Vols]. Moscow, Sovetskaya entsiklopediya Publ., 1962. 1088 clmns. Available at: http://feb-web.ru/feb/ kle/kle-abc/default.asp (accessed on 16 March, 2020). (In Russ.)

10. Shidfar B. Ya. Obraznaya sistema arabskoy klassicheskoy literatury (VI-XII vv.) [The System of Images of Classical Arabic Literature (the 6th-12th Centuries)]. Moscow, Nauka Publ., Glavnaya redaktsiya vostochnoy literatury Publ., 1974. 256 p. (In Russ.)

11. Al-Ğāḥiz Abū 'Uțmān. Kitāb al-qiyyān [A Book About Singers]. In: Rasā’il al-Ğāhiz [al-Ğāhiz’s’ Treatises]. Al-Qāhira, Maktabat al-Ȟanağī Publ., No date, part 2.497 p. (In Arabic) (a)

12.Al-Ğāḥiz Abū 'Uțmān. Kitāb muhāfarat al-ğawārī wa-l-gìilmān [Book of Praise for Girls and Young Men]. In: Rasä’il al-Ğähiz [al-Gāhhiz's Treatises]. Al-Qāhira, Maktabat al-Ȟanağì Publ., No date, part 2. 497 p. (In Arabic) (b) 
13. Al-Ișfahānī Abū al-Farağ. Kitāb al-Ag̀ānī [Book of Songs]. Bayrūt, Dār șādir Publ., 2008, vol. 1. 274 p. (In Arabic) (a)

14. Al-Ișfahānī Abū al-Farağ. Kitāb al-Ag̀ānī [Book of Songs]. Bayrūt, Dār șādir Publ., 2008, vol. 9. 254 p. (In Arabic) (b)

15. Al-Ișfahānī Abū al-Farağ. Kitāb al-Ag̀ānī [Book of Songs]. Bayrūt, Dār șādir Pubi., 2008, vol. 22. 238 p. (In Arabic) (c)

16. Dayf Šawqī. Tàrīh al-adab al-'arabì. Al-'Asr al-islāmī [History of Arabic Literature. The Era of Islam]. Al-Qāhira, Dār al-Maārif Publ., 1963, vol. 2. 491 p. (In Arabic)

17. Ḥusayn Țāhā. Hadịt al-arba'ā' [Conversations on Wednesdays]. Al-Qāhira, Dār al-Ma ārif Publ., No date, part 1. 317 p. (In Arabic)

18. Ibn an-Nadīm. Al-Fihrist [Catalog]. No date. 545 p. (In Arabic)

19. Ibn Qutayba ad-Dīnawarī. Kitāb aššši'r wa-šs-šu'arä' [A Book About Poetry and Poets]. Leiden, Brill Publ., 1902. 653 p. (In Arabic)

20. Bielawski Józef. Klasyczna literatura arabska [Classical Arabic Literature]. Warszawa, Dialog Publ., 2012. 351 p. (In Polish)

21. Brockelmann Carl. History of the Arabic Written Tradition. Leiden-Boston, Brill Publ., 2016, vol. 1. 617 p. (In English)

22.Brockelmann Carl. History of the Arabic Written Tradition. Leiden-Boston, Brill Publ., 2017, vol. 1 (supplement). 1047 p. (In English)

23. Grunebaum Gustave E. von. Growth and Structure of Arabic Poetry A. D. 500-1000. In: The Arab Heritage. New York, Russell and Russell Inc. Publ., 1963, pp. 121-141. (In English)

24. Jacobi Renate. Singers and Musicians. In: Encyclopedia of Arabic Literature. London, New York, Routledge Publ., 1998, vol. 2, pp. 724-725. (In English) (a)

25. Jacobi Renate. 'Udhrī Poetry. In: Encyclopedia of Arabic Literature. London, New York, Routledge Publ., 1998, vol. 2, pp. 789-791. (In English) (b)

26. Jayyusi Salma K. Umayyad Poetry. In: Arabic Literature to the End of the Umayyad Period. London, New York, Cambridge University Press Publ., 1983, pp. 387-432. (In English)

27. Khairallah A. E., Love, Madness and Poetry: An Interpretation of the Mağnūn Legend. Beirut, 1980. 162 p. (In English)

28. Kilpatrick Hilary. Ahbār manzūma: the romance of Qays and Lubnā in the Ag̀̄āni. In: Festschrift Ewald Wagner zum 65. Geburdstag [Festschrift Ewald Wagner for the 65th Birthday]. Beirut, 1994, vol. 2, pp. 350-361. (In English) 29. Kilpatrick Hilary. Ibn 'A'isha. In: Encyclopedia of Arabic Literature. London, New York, Routledge Publ., 1998, vol. 2, p. 308. (In English)

30. Kinany A. Kh. The Development of Gazal in Arabic Literature (Pre-Islamic and Early Islamic Periods). Damascus, Syrian University Press Publ., 1951. 382 p. (In English)

31. Lord Albert B. The Singer of Tales. New York, Athenium Publ., 1971. 309 p. (In English)

32. Sadykhova Arzu A. Formation of Plot Canon in Arabic Literature: The Case of Love Stories About Poets of Bedouins. In: Borders and Beyond. OrientOccident Crossings in Literature. Wilmington, Vernon Press Publ., 2018, pp. 57-68. (In English) (a) 
33. Sadykhova Arzu A. Zerwanie z kanonem: dwie nietypowe historie romantyczne $\mathrm{w}$ arabskiej literaturze średniowiecznej [Break With the Canon: Two Unusual Romantic Stories in Arabic Medieval Literature]. In: Świat arabski w języku, literaturze i kulturze [The Arab World in Language, Literature and Culture]. Toruń, Adam Marszałek Publ., 2018, pp. 117-126. (In Polish). (b)

34. Seidensticker Tilman. Qays ibn Dharị. In: Encyclopedia of Arabic Literature. London, New York, Routledge Publ., 1998, vol. 2, pp. 635-636. (In English)

35. Skarzynska-Bochenska Krystyna. Qays et Lubnā - Mağnūn et Laylā. Le mythe de l'amour platonique selon les chercheurs arabes et européens - et mes decouvertes concernant ce sujet dans Le livre des chansons (Kitāb alAg̀ānī) d'Abū al-Farağ al-Iṣbahānī (X-me siècle J. C.) [Qays and Lubnā Mağnūn and Laylā. The Myth of Platonic Love According to Arab and European Scholars - and my Findings About it in The Book of Songs (Kitāb al-Ag̀ānī) by Abū al-Farağ al-Iṣbahānī (the 10th Century J. C.]. In: Rocznik Orientalistyczny, 2009, vol. 62, 1, pp. 137-145. (In French)

36. Veccia Vaglieri. (al-)Husayn b. Ali b. Abi Talib. In: The Encyclopaedia of Islam. Leiden, Brill Publ., 1986, vol. 3, pp. 607-615. (In English)

37. Wright Owen. Music and Poetry, Medieval. In: Encyclopedia of Arabic Literature. London, New York, Routledge Publ., 1998, vol. 2, pp. 555-556. (In English) 